\title{
Influence of Job Motivation on Basic School Teacher Retention in the Somanya Circuit of Eastern Region in Ghana Education Service
}

\author{
E, Owusu-Acheaw ${ }^{1}$, and D., Bakker-Edoh ${ }^{2}$ \\ 1 Mount Mary Training College, Somanya, Ghana \\ ${ }^{2}$ Koforidua Technical University, Koforidua, Ghana \\ 2Correspondence:dymphnaedob@gmail.com
}

\begin{abstract}
The study set out to examine the influence of motivation on teacher job performance and on teacher retention in the Somanya Circuit of the Ghana Education Service. Generally, teachers in Ghana tend to leave the teaching profession despite various interventions such as single salary spine and best teacher award scheme put in place. Teachers in the Somanya Circuit did not stay and work for more than three years but there is no documented reason why. Therefore the study was done to find out why and whether they were not motivated enough. The researcher adopted the descriptive survey design. A sample of 170 teachers selected by stratified random sampling was used. Questionnaires was the main instrument used and the data collected was analysed with the statistical tool SPSS. The findings of the study revealed that basic school teachers in public school in the Somanya circuit were highly motivated, but they rated their mode of promotion and salary levels to be rather low. The results also revealed that respondents generally disagreed that the factors of motivation like salary and monetary compensation, leave benefits, good retirement plan, promotion, job security, opportunities for extra income, health benefits, accommodation, free time during holidays and more time to attend to other issues do influence their level of motivation. It was further revealed that some basic school teachers have been retained in the Somanya circuit not necessarily based on the motivation avenues presented to them but on other factors Finally, it was recommended that Yilo Krobo Municipal Directorate of the Ghana Education Service should continue to motivate teachers by providing adequate supervision, recognition and appreciation to motivate basic school teachers in the Circuit.
\end{abstract}

Keywords: basic education, public school, quality, motivation, teacher retention

Citation: E, Owusu-Acheaw, and D., Bakker-Edoh. Influence of Job Motivation on Basic School Teacher Retention in the Somanya Circuit of Eastern Region in Ghana Education Service, 2020; 5(3): 12-36.

Received: April 8, 2020

Accepted: September 30, 2020 


\subsection{Introduction}

Teacher attrition is a global issue that requires a critical look from all partners of education. Teachers in most developing countries are 'semi-professionals' mainly because of their relatively limited levels of education and training compared to professional occupations such as doctors, engineers and lawyers (Bennell, 2004). University graduates and secondary school leavers in many countries resort to teaching as last employment avenue. Consequently, teachers often lack a strong, longterm commitment to teaching as a vocation. Teachers are paid considerably less than the mainstream professions. It is widely argued that the status of teachers in most countries, both developed and developing, has declined appreciably during recent decades (Bennell, 2004). Adu (2005) indicated that teachers are the bedrock for all human learning, and they are the pivot around which citizens are made to realise their full potential in serving their society and nation as well.

Teacher motivation and retention in Africa and South Asia has been well studied with wide range of views which are mostly country specific. However, there seems to be growing concerns that unacceptably high proportions of teachers working in public school systems in many low income earning countries are poorly motivated due to many factors such as low morale and job satisfaction, poor incentives, and inadequate controls and other behavioural sanctions. The excessive politicisation of public education has had a major impact on levels of accountability in many education systems which consequently has adversely affected teacher commitment and motivation. This has resulted in many parents sending their children to nonpublic schools. In some countries, particularly in South Asia, this amounts to a mass exodus of teachers for greener pastures.

The issue of teacher motivation and retention has been a great concern to governments, educationists and other policy makers since the colonial era (Parveen, 2011). This has been largely so due to the conviction that if teachers are well motivated, it would not only have a positive impact on their performance, but would also cause them to remain in the profession. To boost up the morale of teachers and ensure their job satisfaction and performance, the colonial government of Sir Gordon Guggisberg (1919-1927) effected a general increase in salaries of teachers in public institutions in Ghana to revamp their conditions of service and also to retain them in the profession (McWilliam \& Kwamina-Poh, 1975).

The mass exodus of Ghanaian teachers to other neighbouring countries in the 1970s showed that, things were not well with the educational system in Ghana. The trend, though considerably toned down, still continues. This exodus had led to a reduction of teachers which manifest in the Somanya Circuit and various individuals have had the opportunity to raise concern about problems that the Ghana Education Service faces in teacher motivation and retention and how it affects their performance. Students who are directly affected are known to decry the state of affairs where they must frequently adapt to the methodology and demeanour of new teachers of the various subjects. Even when the schools have the required number of teachers, the task of teaching-learning may tend to fall far short of expectation; this could give rise to a boom in part-time teaching jobs in the area. Though immensely profitable for some teachers, it could compel, parents who are anxious about the future of their wards to yield to the financial demands of the teachers involved.

The Somanya Circuit has a lot of social amenities, by Ghanaian standards likely to attract and influence the retention of teachers in the schools located in the area. Some of the social amenities available in the Somanya Circuit are pipe-borne 
water, various telecommunication networks and the presence of radio stations which will contribute immensely to help people to be in touch with others and kill boredom. The availability of electricity supply throughout the area motivates dwellers to aspire to acquire modern electrical and electronic gadgets like radio, television sets and computers. Dwellers are likely to be consequently abreast with the current trends and affairs in and outside Ghana. In spite of the conscious attempt by successive governments at making teaching attractive, teachers do not teach for long periods of time in the area, and that has been an uphill task for the District Education Directorate (District Education Directorate, 2015).

Teachers in the basic schools in Ghana teach for short periods of time and replacements for those who leave tend to be delayed (District Education Directorate, GES, 2015). In the Somanya Circuit of GES teachers are not desirous to stay and teach; whereas some teachers tend to stay for not more than three years only a few stay for over twenty years Furthermore, despite interventions such as the Single Spine Pay Policy and the best teacher award scheme implemented by the state to retain teachers, many teachers plus those in Somanya Circuit continue to leave the teaching profession (Owusu-Acheaw, 2016). The reasons that encourage some teachers to want to stay for long and other reasons that compel some teachers to leave in the Somanya circuit has not been identified.. There is only limited literature on teacher motivation and retention in Ghana. However, there is no information or huge literature gap on teacher motivation and retention for the Somanya circuit. It is against this background that the researcher wanted to find out some factors that influence the motivation, job performance and retention of basic school teachers in public schools in the Somanya Circuit of GES of Eastern Region, Ghana. The conceptual framework of the study was based on the Herzberg two-factor theory of satisfaction or dissatisfaction after considering five other theories. The theory suggests that satisfaction leads to attraction to work and dissatisfaction leads to avoidance of work.

The study was carried out to identify factors influencing motivation of teachers and how that is impacting on the job performance and retention in public basic schools in the Somanya Circuit. The significance of the study was to; i) identify factors that contribute to enhancing motivation and retention of teachers in public basic schools in the Somanya area, ii) reveal the teacher retention rate in the Somanya Circuit of GES, iii) provide a guide for educational administrators and teachers to access and know the factors accounting for teacher motivation and retention in the circuit, iv) help the Ministry of Education and the GES to identify the remedies to implement to help solve the problem in the Somanya Circuit in Ghana.

The main objective was to examine the influence of motivation on teachers' job performance and their retention at the basic school level in the Somanya Circuit of GES in Eastern Region, Ghana. Specifically, the study sought to: i) find out the level of teacher motivation in Somanya Circuit of GES of Eastern Region, Ghana, ii) ascertain the factors influencing teacher motivation in the Somanya Circuit of GES in Ghana, iii) examine the relationship between teacher motivation and retention in Somanya Circuit of GES. iv) determine the impact of motivation on teacher job performance in the Somanya Circuit of the Ghana Education Service. 
Research questions formulated to guide the study were; 1) what is the level of teacher motivation in the Somanya Circuit of the Ghana Education Service? 2) What factors influence teacher motivation in the Somanya Circuit of the Ghana Education Service? 3) What is the relationship between teacher motivation and retention in the Somanya Circuit of the Ghana Education Service? 4) What is the impact of teacher motivation on teacher job performance in the Somanya Circuit of the Ghana Education Service?

\subsection{Empirical Literature}

Motivation is the goal-directed behaviour of people and it involves making people do things in a particular way in order to achieve a result. Robin (1989) defines motivation as the willingness to exert high levels of effort gear to organisational goals. It is the willingness on the part of an individual to productively and efficiently performing at higher levels than required of him or her under normal circumstances for achieving organizational goals (Nayyar, 2005). People become motivated when their course of action leads to achieving a goal and a valued reward that satisfy their needs (Armstrong, 2007, Ofoegbu, 2004). Dornyei, (2001) opined that motivation is responsible for 'why people decide to pursue a goal, how hard they pursue the goal, and how long they sustain the activity'.

A number of theories have been described to explain the effect of teacher motivation on retention. Five of these theories were reviewed, namely needs theory, integrated motivational, Weber's theory of bureaucracy, Coleman's theory and Herzberg two factor theory (Mullins, 2002; Opare, 1998; Weber, 1947; Coleman, 1988; Herzberg et al, 1959 all cited in Owusu Acheaw, 2016). Needs theory suggest people have physiological, security, love, esteemed, and self-actualisation needs and that they are insatiable, always asking for more (Mullin, 2003). The integrated motivational theory is based on individual, situational and job characteristics which suggests 'systems perspective of work motivation'. Therefore individuals join jobs with the hope that their values and desires will be met (Locke, 1984). Werber's theory of bureaucracy implies positions are arranged hierarchically which makes it too impersonal, machine-like and highly routine. Coleman's social capital theory which indicates that the relationship between and among people is important. The Herzberg (1957) two factor theory that listed needs which they termed 'satisfiers' suggest satisfaction and dissatisfaction on job. This theory was adopted. Intrinsic motivation is self-generated factors which includes feeling in-charge, responsible, freedom to act and ability to develop skills and abilities. Extrinsic motivation is things done to motivate people such as increased pay, promotion, praise and punishments among others (Armstrong, 2007). The theories suggests that when people's interests, needs and expectations are blended with the job characteristics and the work environment, the individual will feel highly motivated and will stay on the job. On the contrary, if the needs, interest and expectations does not conform to job characteristics and work environment, dissatisfaction will set in. The individual may then be compelled to leave the job (Locke, 1984; Mullins, 2003).

Teacher motivation could be defined as those factors if not available to the teacher could affect their performance. Most teachers work in difficult and very challenging conditions in primary schools mostly in rural remote areas. Lack of facilities such as staffrooms, classrooms, teaching and learning materials are clearly demotivating (Ofoegbu, 2004). Poor housing conditions, lack of housing, large classes, undisciplined and unruly students have all negatively affected teachers' motivation 
(Dornyei, 2001). In addition, teachers usually have high teaching loads and some teach more than one class. Teachers teaching lower classes are faced with large and unmanageable classes. Class sizes of over 100 pupils per class are common in some urban areas in Ghana. Understandably, teachers in such schools often seek transfer to 'better' schools. High transfer rates are symptomatic of widespread teacher discontentment with working conditions and generally low motivation. School leaders and management have not helped teachers to be positive about their schools and work. Where leadership is positive, teachers have higher morale.

It is evident in the literature that studies from developing countries establish that extrinsic factors such as salary are important in determining teacher job satisfaction. Bennel (2004) revealed that in developing countries teachers' salary and other financial benefits were far too inadequate to provide teachers with reasonable standard of living and survival needs of households (EFA report, 2005). Studies in Bangledeshi and Cyprus revealed that teachers were dissatisfied with their salary levels and that this issue must be taken seriously as a motivational intervention (Tasnim, 2006; Zembylas \& Papanastasious, 2004). Akinwumi (2000) observed that teachers with low income only expect a reasonable salary increase to significantly enhance their commitment and performance (cited in Adelabu, 2005). Tansim (2006) discovered that teachers were not motivated as a result of higher dissatisfaction with not being involved in decision-making process. Tansim (2006), Akyeampong and Bennell (2007) also emphasizes that primary school teacher motivation declined in recent years particularly in the urban areas because of high living cost and workload in Ghana. Bame (1991) states that job dissatisfaction for the Ghanaian teachers include inadequate or poor salary, no opportunities for promotion, lack of recognition in teaching, poor relationships among teachers themselves and frequency of transfers in teaching.

Adesina (1990) notes that teachers leave one location to another for higher earnings and school facilities that promote instructional efficiency. Disagreement with administrative policies and personal inability to meet higher professional standards are other factors which according to him contribute to teacher turnover. Chapman (1994) asserted that qualified teachers leave the teaching profession at the point when compensation differs significantly from other profession. He also contends that teacher turnover can be effectively eliminated by raising salaries high enough. Chapman (1994) further went on to enumerate other causes of teacher turnover as government policies, poor working conditions, low incentives, limited opportunities for advancement, low recognition or professional status, low salaries and fringe benefits among others.

The prosperity of a nation requires a continuous supply of highly qualified experts including teachers. Teacher retention thus becomes the hinges pin upon which the attainment of set national goals rest. Myron cited in Owusu Acheaw (2016) maintained that in periods of prosperity, when salaries in other professions are relatively higher, there is tremendous exodus from teaching. Teachers tend to leave the rural areas where salaries and working conditions are least attractive but where educational services are most needed, to ironically urban areas where salaries and working conditions are superior. Studies in Nigeria and Ghana have shown that teachers are dissatisfied in serving public schools in rural areas because of poor salary, dilapidated and inadequate facilities as well as lack of better incentives such as accommodation (Adelabu, 2005, Tsegah, 2004; Sam et al, 2014). Hence this action of teachers' show that they are mostly motivated by economic considerations as other groups despite the current believe that teachers, by their greater devotion to service, are a selfless group of people. Chamberlain and Kindred cited in Owusu Acheaw (2016) observed that the attitude of some teachers 
deter many young people from taking teaching as a profession. According to them, many embittered and frustrated teachers have been guilty of telling their students not to go into teaching because of the few rewards and much abuse. However, they acknowledge efforts by some teacher to encourage young ones to develop interest in teaching. Hanson cited in Owusu Acheaw (2016) posits that teachers' salaries must be flexible such that they provide a means for facilitating adjustments in the distribution of teachers between rural and urban areas. He argues that higher salaries in the rural areas might be expected to offset the urban preference. He testifies to the rise in number and quality of elementary and secondary school teachers in America between 1950 and 1960. His reasons being many people entering teaching because of the alleged teacher shortages coupled with high rise in salaries.

Quality education has been defined differently by separate agencies but UNICEF stresses on five desirable attributes namely learners, environment, content, processes and outcomes that are based on the rights of a whole child and all children to survival, protection, development and participation (UNICEF, 2000; 2000 Dakar Framework for Action, all cited in Armstrong et al, 2005) In Ghana the quality of education is low despite the different interventions and international support from donors to improve quality basic education (Ankomah et al, 2005; Tsegah, 2004). Those who attend schools in cities, town, regional centers and the national capital receive better quality education than the rural areas (Ankomah et al., 2005, cited in Akuoka et. al., 2001). There is also a disparity between geographical areas, where developed areas had better quality education than less developed areas. Parents have been shown to enrol their children in private schools because they believe the schools provide better quality education and performance than the public schools (EARC, 2000). The difference was attributed to quality of supervision and better management of instructional time (Ankomah et. al., 2005). In Ghana though quality of education is low, it is lower in public schools than private schools and lower in rural area than urban areas (Tsegah et al. 2004).

Teacher motivation is important to many policy makers because of its correlation with the quality of education. All national policies and action plans, influenced by international commitments like Millennium Development Goals (MDGs) and Education for all (EFA), highlight the importance of teachers and the pivotal role they play in education. Ghana government, over the years, has committed a lot of resources aimed at enhancing the status, morale and professionalism of teachers. This is evident in the huge sums of budgetary money allocated to education in developing countries but still the quality of education is low (UNESCO, 2006). Winbilah (1999) said that most governments already know that raising salaries higher retain teachers, but wish to retain trained teachers at the lowest possible cost. Sebiwoliba (2013) stressed that for any human capital to have appreciable impact on the socio-economic development then it is essential to investment in education, training, learning, health and nutrition of people. This reality implies that teachers are pivotal in the social and economic development of their societies.

The review notes that teachers leave teaching when there are significant disparities in compensation of what they would have received in other jobs. The highlights also indicates that many teachers do not stay long in the teaching profession and in basic schools in particular because of the negative attitude of the employer and public towards the profession. It is based on this background that the study sought to explored teacher motivation and job satisfaction within a metropolis. 


\subsection{Methodology}

\subsection{Research Design}

The researcher adopted the descriptive survey design which reports the way things are. The use of descriptive survey is advantageous because a questionnaire can be sent to a large number of people and data can be collected, quantified and analysed using descriptive and or inferential statistics. The descriptive survey design was chosen because it produces reliable amount of responses from a wide range of people. Furthermore, it provides a meaningful impression of events by explaining people's perceptions and behaviour on the basis of information gathered at a point in time. The descriptive survey was appropriate in obtaining much information that were used in generalisation for the entire population.

\subsubsection{Population}

The target population comprised of all teachers of the public basic schools in the Somanya municipality of the Ghana Education Service (GES). The accessible population however consisted of 285 primary and junior high school teachers in public basic schools in the Somanya Circuit of GES. It included 179 primary school teachers and 106 junior high school teachers as the population. The primary teachers included 81 male and 98 female while the junior high school teachers included 67 male and 39 females in the circuit (Owusu-Acheaw \& Bakker-Edoh, 2020b).

\subsubsection{Sample and Sampling Procedure}

According to a list available at the Ghana Education Service Directorate of Education in the Yilo Krobo municipality, there were 15 primary schools and 11 junior high schools in the Somanya Circuit. Ten primary schools and six junior high schools were selected for the study using random sampling technique. The table of Krejcie and Morgan (1970) was applied to select the sample size for the study. The table indicates that when there is a population of 285 , a sample of 170 should be selected. A sample size of 170 teachers was selected proportionally from sixteen basic schools for the study. The simple stratified random sampling procedure (lottery method) as proposed by Borg and Gall (1989) was then used to select the teachers for the study. This sampling procedure was done to ensure that respondents were given fair and equal chance to participate in the study (Gay, 1996). The staff list of names of teachers together with their staff identification numbers was used in each of the sixteen schools. Hence 170 teachers from a total of 285 teachers in the basic schools of the Somanya Circuit of the GES were selected for the study.

\subsection{Research Instrument}

The instrument that was used for data collection was a self-developed questionnaire based on respondent's teachers who are highly literate. In the view of Bourdon, Goodman, Simpson and Koretz (2005), it is acceptable, has quick response, consistency, and easy to conduct. Moreover, it is a much quicker means of collecting data from a large population. Questionnaires were presented to the teachers on account of their literacy level, large number and for the fact that it would be an additional constraint if all the teachers were to be interviewed. Moreover, it will be time consuming on the part of the researcher. 
The questionnaire was made of twenty-nine (29) items. It was grouped into five sections. Section A which consisted of the first four items sought to find out the background information of respondents such as age, gender, educational level and teaching experience. Sections B, C, D, and E consisted of items related to the various research questions. The questionnaire was made up of mainly close ended items.

\subsection{Validity of Items and Pre-testing}

The instrument was first prepared by the researcher and later shown to the supervisors who scrutinized the items one after the other and offered suggestions for modifications for its content validity.

The instrument was pre-tested before being used in the main study to avoid ambiguous items. The questionnaire was pretested in two basic schools in the Krobo Odumase Circuit. The two schools were selected because they had similar characteristics such as the educational level of teachers, resources available, pupils handled and so forth. The two schools were Mt. Mary Demonstration Primary and Atua St Paul JHS. In all 20 respondents were involved in the pre-testing. The pre-testing was done to determine the reliability of the questionnaire items, to assess the appropriateness of the questionnaire and its practicality. It also helped check respondents' understanding of the language and the wording used. The data collected was processed with the help of SPSS and the Chronbach Alpha was used to test for its reliability coefficient. The reliability coefficient was 0.821 .

\subsection{Data Collection Procedure}

The researcher obtained permission from the Municipal Director of GES and then the Director of GES directorate of Yilo Krobo Municipality by explaining the purpose of the study using an introductory letter from the Department of Educational Foundations, University of Cape Coast. The researcher then proceeded to the various schools selected for the study to obtain their consent and to administer the questionnaires. The respondents involved in the study were assembled and the purpose and the procedure of the exercise were explained to them. The teachers concerned were informed about the exercise a day before the encounter. Questionnaires were then distributed to the prospective respondents after the explanation of the purpose of the study. Assistance of some teachers in the various schools were sought to help in the collection of the data. The administrations of the questionnaire were done personally.

\subsection{Data Analysis Procedure}

The responses to the questionnaire were checked, edited and coded and were statistically analyzed using descriptive statistics with the help of the Statistical Product and Service Solutions (SPSS). Descriptive statistics namely frequencies and percentages, means and standard deviation were used to analyse the various research questions. For example, research question one was analysed using frequencies and percentages, research question two was analysed using means and standard deviations to show distribution of responses. Research questions three was analysed using correlation and the Pearson's correlation momentum coefficient. This was to determine the strength of the relationship and to show the distributions of 
responses of respondents concerning the questions raised. The last research question was analysed using simple regression analysis to determine the impact of the motivational levels of teachers and their performance.

\subsection{RESULTS}

The results from the data are presented in this section sequentially, based on the set research questions that drove the study.

Research Question One: This research question sought to identify the level of motivation of basic school teachers in public schools in the Somanya circuit of the GES. This section of the questionnaire presented basic school teachers in the Somanya Circuit with some elements of motivation and were required to respond by indicating the availability or otherwise of these elements in the circuit. Responses given to this query are presented in Table 1. In the table, Very High responses are represented by $(\mathrm{VH})$, High $(\mathrm{H})$, Low $(\mathrm{L})$ and Very Low (VL).

\section{Table 1: Level of Motivation}

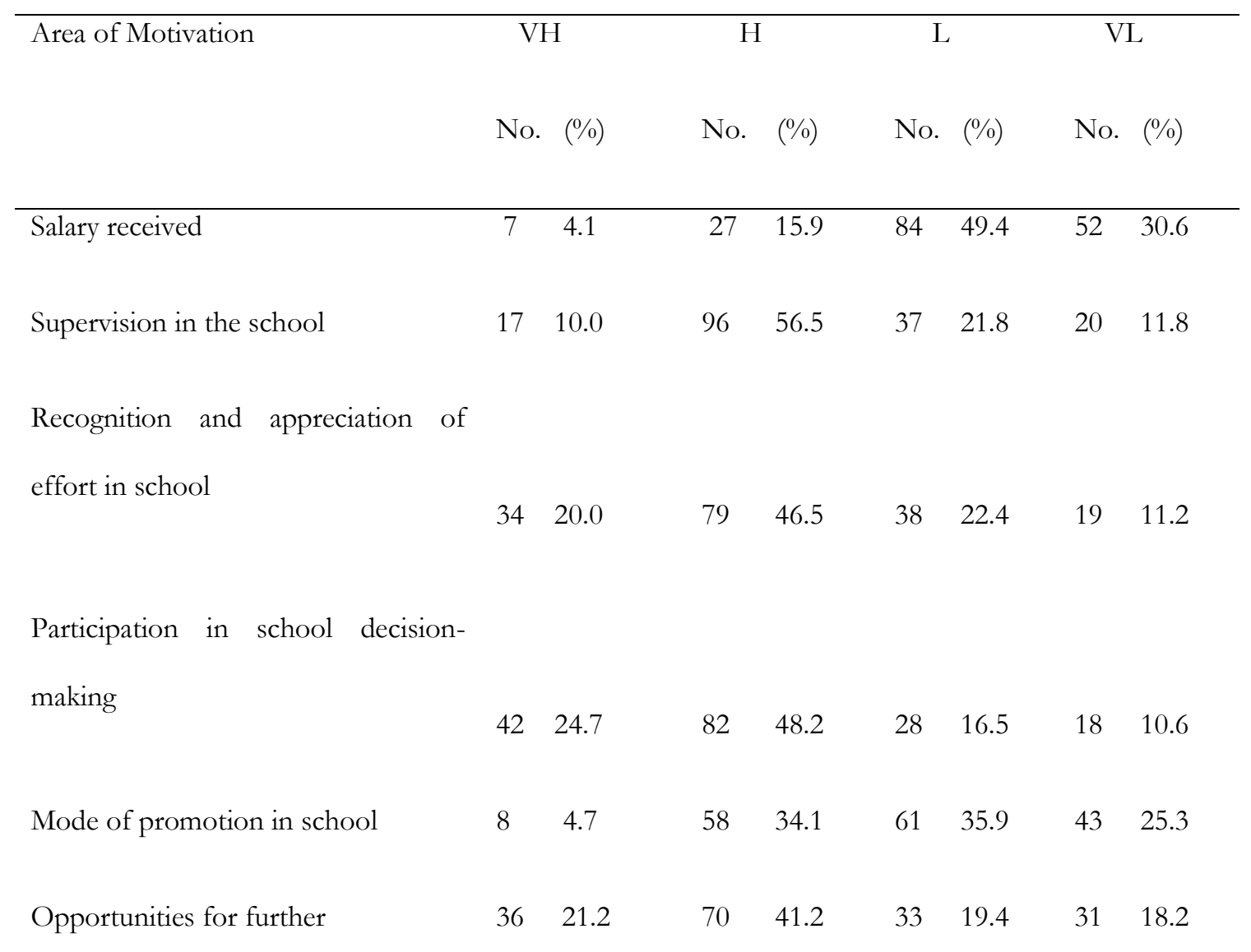

Studies

Source: Field Data, 2015, N = 170 
As indicated in Table 1, respondents highly rated the level of motivation in terms of supervision, recognition and appreciation, participation in school decision-making, and opportunities for further studies. Respondents rated these elements as highly being practiced and enforced in the Somanya Circuit. One hundred and thirteen (66.5\%) respondents rated the supervision in their schools as being high and in turn put them on their toes to work diligently and hard. Statistically 96(56.5\%) respondents rated supervision in their schools as high while 17(10.0\%) also rated it as very high (Table 1). Only 20(11.8\%) respondents rated supervision in their schools as being very low. Similarly, as much as $82(48.2 \%)$ respondents rated their participation in school decision-making process as high. Forty-two $(24.7 \%)$ respondents also rated this query as very high. Most respondents numbering 113 (66.5\%) also rate recognition and appreciation of their work as high among whom $20 \%$ rated it as very high.

However, majority of the respondents, 136(80.0\%), rated their salary level as low and thus, does not highly motivate them in their line of duty. On this issue, 84(49.4\%) respondents, as evident in Table 1, rated their salary level as low, with $52(30.6 \%)$ respondents also rating it as very low. Just 7(4.1\%) respondents rated their level of salary as being very high. Out of the total sample of 170 respondents, 104(61.2\%) respondents rated the mode of promotion in the Somanya Circuit as being low. To them, the chances for a teacher in the Somanya Circuit to advance through promotion are very low.

Research Question Two: This research question sought to assess the factors that influenced teacher motivation in the Somanya Circuit of the GES. Section C of the research questionnaire presented to respondents a series of factors that influenced teacher motivation. On a four-point Likert scale, respondents were asked to indicate the extent to which they agreed to these factors. Responses gathered are presented in Table 2 with means and standard deviation to show the distribution of responses given by respondents. The mean scores are interpreted as;

2.5 and Above $=$ Agree

2.4 and Below $=$ Disagree 
Table 2: Factors Influencing Teacher's Motivation

\begin{tabular}{lcc}
\hline \multicolumn{1}{c}{ Factors } & M & SD \\
\hline Salary and Monetary Compensation & 2.29 & 1.10 \\
Leave Benefits & 2.05 & .92 \\
Good Retirement Plan & 2.24 & 1.05 \\
Promotion & 2.57 & .88 \\
Job Security & 2.36 & 1.06 \\
Opportunities for Extra Income & & 1.06 \\
Health Benefits & 2.10 & 1.07 \\
Accommodation & 1.96 & 1.10 \\
Free Time during Holidays & & .89 \\
More time to Attend other Issues & 2.244 & \\
\hline Mean of Means/ Standard Deviation & & .87 \\
\hline Source: & & \\
\end{tabular}

Source: Field Data, 2015, N = 170

From Table 2, M is the mean and SD is the Standard Deviation. Means for responses given by respondents concerning factors that influence teacher motivation aid to understand the level of agreement respondents made to these factors. As evident in Table 2, respondents generally disagreed that the factors of motivation presented to them in the questionnaire do influence their level of motivation. Most of the items had a mean score falling below 2.5, indicating that, respondents disagreed to majority of the items. To them, the factors presented to them did not manifest in their career and thus, did not influence their level of motivation. On the issue of salary and monetary compensation influencing the teacher's work, a lower mean $(\mathrm{M}=2.29, \mathrm{SD}=1.10)$ was computed indicating that, basic school teachers of the Somanya Circuit disagreed 
that monetary issues in their circuit did influence their level of motivation. A higher standard deviation value (1.10) shows how heterogeneous the disagreement was. A lower mean score (1.92) for instance was realised for the query that sought to find out if accommodation in the Somanya Circuit influenced teachers' motivation level. Other factors that respondents disagreed to influencing their motivation were leave benefits (2.05), good retirement plan (2.24), health benefit (1.96), opportunity for extra income (2.10), more time to attend other issues (2.21) and accommodation (1.92).

None the less, respondents agreed to a few of the queries. The descriptive statistics presented in Table 2 show that respondents agreed that promotion was a factor that influenced their level of motivation $(\mathrm{M}=2.57, \mathrm{SD}=.88)$. In furtherance, the agreements made by the respondents are homogeneous as well. The different nature of the responses which is positive is not widely dispersed (.88). Similarly, respondents also agreed that opportunities for free time during holidays also influenced their motivation. A mean score of 2.74 was computed for this query.

The total mean of means calculated for Table 2 is 2.244 with a total standard deviation value of 1.0. Basic school teachers in Somanya Circuit thus disagreed with the factors presented to them as evident in their circuit, to be influencing their motivation rate. A higher standard deviation value indicates how heterogeneous the responses were.

Research Question Three: This research question sought to ascertain the relationship between teacher motivation and retention in the Somanya circuit. A Pearson's Moment Correlation Coefficient was computed to answer this question and the results are presented in Table 2.

Table 2: Relationship between Teacher Motivation and Retention

\begin{tabular}{lccc}
\hline & \multicolumn{3}{c}{ Teacher Motivation to Retention } \\
\cline { 2 - 4 } & Pearson Correlation & Sig. (2-tailed) & $\mathrm{N}$ \\
\hline Retention & $-.346(* *)$ & .000 & 170 \\
& & & \\
\hline
\end{tabular}

${ }^{* *}$ correlation is significant at the level of 0.01 (2-tailed).

Source: Field Data, 2015

A Pearson correlation coefficient was computed to assess the relationship between teacher motivation and retention in the Somanya circuit of the GES. There was a negative correlation between teacher motivation and retention in Somanya circuit 
$(\mathrm{r}=-.346$, sig. $=.00, \mathrm{n}=170)$. The two variables as they exist in Somanya circuit are not mutually complementary. They are negatively correlated. The retention rate of teachers varies with their level of motivation. Thus, basic school teachers have been retained in the Somanya circuit not necessarily based on the motivation avenues presented to them. The Pearson correlation coefficient for teacher motivation and retention as indicated in Table 2 is -.346 , which is significant $(\mathrm{p}<.01$ for a two-tailed test, based on a sample of 170 respondents). The teacher motivation and retention have statistically significant linear relationship $(\mathrm{p}<.01)$ though the direction of the relationship is negative. Even though the correlation computed is negative and not mutually complementary, a significant value of .00 indicates that teacher motivation in itself is a factor to retention. The magnitude of the relationship between the variables is strong $(1</ \mathrm{r} />.3)$; indicating that motivation is a predictor to retention.

Research Question Four: This research query sought to find out from basic school teachers of Somanya circuit, the impact of motivation on their job performance. It was concerned with finding out the performance of basic school teachers based on their motivation level. A simple linear regression was computed using SPSS to determine how the independent variable (teacher motivation) predicts teacher job performance (dependent variable). The results are presented in Tables 3 and 4 . 
Table 3: Regression Model Result of Teacher Motivation predicting Teacher Job Performance

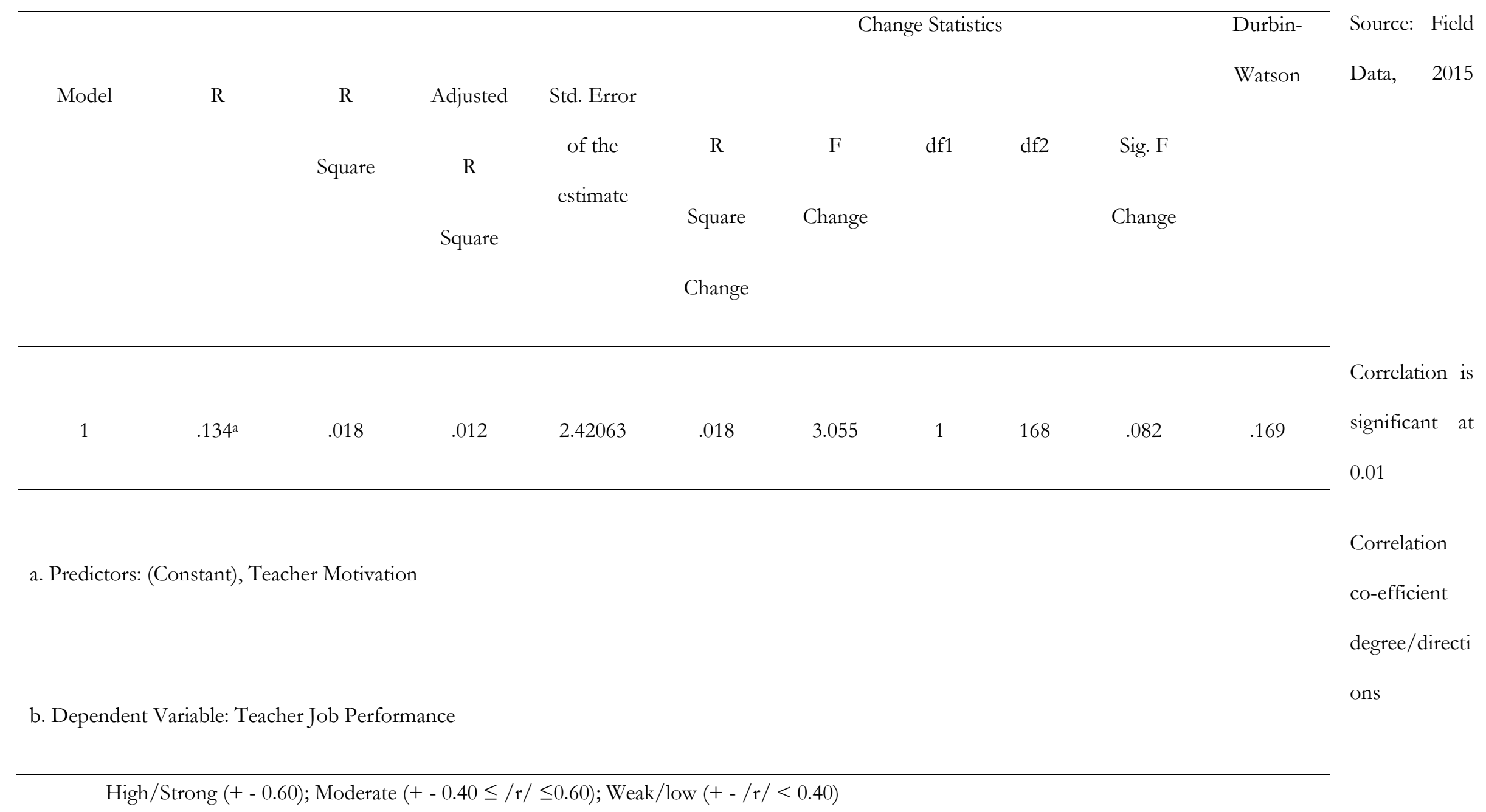


Table 3 presents the linear regression model which indicates that the constant variable (teacher motivation) does not predict teacher job performance of basic school teachers in Somanya circuit, $R^{2}=.018, R^{2}{ }_{a d j}=.012, F(1,168)=$,3.055 , $\mathrm{p}<0.01$. This model account for only $18 \%$ of variance in teacher job performance. In effect, teacher motivation in the Somanya circuit accounts for $18 \%$ of teacher job performance. The correlation value, $r=.134$, indicates that the relation between the variables though positive is weak. The model as presented in Table 3 also reveals that the linear regression model (Fchange statistic $=3.055 ; \mathrm{p}<0.01)$ is significant and the Durbin-Watson shows that the model is fit at .169 .

Table 4 reveals the standardised and unstandardised regression weights for the linear regression analysis computed for teacher motivation, predicting teacher job performance. The standardised regression coefficient (beta weight) for teacher motivation is -.134 , which is negative, $\mathrm{t}$-value is -1.748 (which is less than standard 2.00) and P-value is .082 (which is greater than 0.01). This implies that for every change in the motivation of teachers, the job performance of teachers will in turn decrease by a multiple of -.134 standard deviations. 
Table 4: Regression Co-efficient Analysis of Teacher Motivation predicting Teacher Job

Performance

\begin{tabular}{|c|c|c|c|c|c|c|c|c|}
\hline & \multicolumn{2}{|c|}{ Unstandardised } & Standardised & & & \multicolumn{3}{|c|}{ Correlations } \\
\hline & \multicolumn{2}{|c|}{ Coefficients } & \multicolumn{3}{|l|}{ Coefficients } & \multirow{3}{*}{ Zero-order } & \multirow{3}{*}{ Partial } & \multirow{3}{*}{ Part } \\
\hline & & Std. & & & & & & \\
\hline Model & B & Error & Beta & $\mathrm{T}$ & Sig. & & & \\
\hline \multicolumn{9}{|l|}{1} \\
\hline & 15.081 & .904 & & 16.690 & .000 & & & \\
\hline Teacher & -.103 & .059 & -.134 & -1.748 & .082 & -.134 & -.134 & -.134 \\
\hline Motivation & & & & & & & & \\
\hline
\end{tabular}

a. Dependent Variable: Job Performance

Source: Field Data, 2015 


\subsection{DISCUSSIONS}

It is clear from the results that motivation is an important intervention to make people aspire to teach better. Thus when teachers are provided with the requisite incentives, especially the newly employed, people will join the teaching profession as well as provide quality service. The study revealed the level of motivation among respondents. Most respondents highly rated supervision (66.5\%), recognition and appreciation (66.5\%), participation in school decision-making (72.9\%), and opportunities for further studies $(62.4 \%)$ as important motivational tools. As Bennell and Akyeampong (2007) puts it, teacher motivation critically depends on effective management at the school level. When school managers are able to supervise the activities of teachers, teachers are highly motivated to be responsible.

Bacharach and Bamberger (1990) asserts that should participation in decision making fall short of expectation, teachers will have low professional commitment and leave post. Respondents admitting that they were involved in school decision making implies that they have higher professional commitment since they felt part of the school's decision making body. This auger well for the Somanya Circuit since higher professional commitment will ensure higher student performance. The results also indicated that recognition and appreciation (66.5\%), as well as opportunities for further studies (62.4\%) motivated the respondents in the study. This finding confirms Chapman's (1994) argument that some causes of teacher turnover were limited opportunities for advancement, low recognition or professional status, government policies, poor working conditions, low incentives, and fringe benefits among others. On the whole, majority of the respondents rated these elements as being highly effected in the Somanya Circuit of the GES.

Another finding was that most respondents rated their salary levels as low. Herzberg et.al. (cited in Owusu Akeaw, 2016) opine that when salary of an organisation is disappointing, workers tend to be dissatisfied with their job. Therefore the respondents might not be satisfied with their job and likely to perform below expectation. Many respondents 104(61.2\%) rated the mode of promotion in the Somanya Circuit as being low. To them, the chances for a teacher in the Somanya Circuit to advance through promotion are very low. This could be because promotion in the educational system is demanding, cumbersome and very complicated hence many teachers are not encourage 
to apply and this affect their job performance. Other studies have confirmed this finding (Sam et al. 2014; Tsegah, 2006; Akuoku et al, 2012).

The factors that influence teacher motivation was investigated in the study. Respondents agreed that promotion (2.54) and free time during holidays (2.74) were factors that influence their motivated. To basic school teachers in the Somanya circuit, their mode of promotion as well as structures put in place for promotion influenced their motivation in their line of duty. This could be because promotions have the tendency of being delayed and not transparent hence teachers have no confidence in the process. In addition, teachers sometimes do other jobs such as extra classes to complement their low salaries hence their free time are important to them. The study also revealed that job security $(2.36 \%)$, good retirement plan (2.24\%), and salary and monetary compensation $(2.29 \%)$ fell below 2.5, suggesting respondents disagree that these factors motivated them. The level of disagreement is however only minimal, slightly below 2.5. Since most of the mean values, as indicated in Table 2 are below 2.4, the researcher realised that basic school teachers in the Somanya Circuit of the GES are mostly not presented with motivational avenues. They were not motivated with a good retirement plan, leave benefits, job security or even accommodation. This contradicts the finding of Abdul-Rahaman el. al. (2018) that job security had the fair likelihood of keeping teachers in deprived areas. When GES teachers are posted to new district their salaries delay for months, and if their names are not transferred to the new district on time their names are deleted from the payroll. Teachers are therefore concern about their job security. Basic school teachers of the Somanya circuit disagree that better salary motivates them to work harder and be retain in teaching service. This can be quite alarming and worrying, as this can even lead to turnovers among teachers and will make teaching profession less appealing (Johnson, et al., 2005).

Though teachers claimed they were not well paid, they still remained in the profession. This finding confirms that of Hanson et al. (2004), and Gritz and Theobald (1996) that, poor salary of some teachers does not affect their decision to remain in the profession, rather, a factor to eliminate dissatisfaction. Akuoko, Dwumah \& Baba, (2012) revealed that majority $(58.3 \%)$ of their study respondents indicated that they taught because they were interested in the profession. Dornyie (2001) opined that as a vocational goal some teachers have an internal desire to provide knowledge and value in teaching to educate people. 
To find out about the relationship between teacher motivation and its impact on education a regression analysis was conducted. The linear regression model results indicated that teacher motivation in the Somanya circuit accounts for only $18 \%$ of teacher job performance. The standardised regression coefficient of -0.134 obtain implies that the job performance of teachers will decrease by -0.134 standard deviation for every change in teacher motivation. Thus teacher motivation is negatively correlated to quality teacher delivery in schools in Somanya circuit. This finding contradicts other studies that revealed that motivation of teachers would significantly improve teacher commitment and performance (Akuoko, Dumah \& Baba, 2012; Ubom, 2002). The difference could be that teachers in Somanya circuit were either not aware or presented with appropriate motivation packages.

As part of this study but published elsewhere (Owusu-Acheaw \& Bakker-Edoh, 2020), it was found from the respondents' demographics that more females, aged 20-40 years, with first degrees, and have taught for many years formed majority of the study group. More respondent female teachers observed in the study contradicts others (Hofstede, 2005; Tasnin, 2006) who indicated that women are concern with taking care of home, children and people as such few are in formal occupational environments. In Ghana the cultural belief that women have reproductive and domestic roles in society also makes it extremely difficult to find them in formal sectors like teaching. The more female teachers observed in the study is helpful to the circuit. The active working age group in Ghana falls within 20-49 years where most of the study respondents were. The agitation for better living and working conditions from the mainly 20-40 year old respondents was probably because most were married with high social and economic needs. The introduction of many distance education programmes in Ghana could also account for the majority of the respondents having furthered their education and teaching in Somanya circuit (Tasnin (2006). Thus as indicated in the demographic survey, though teacher motivation might not be optimal in Somanya circuit, those at post are in the active working group and are well qualified to deliver, which will be beneficial to the community.

Generally, though teachers in the Somanya circuit are not externally well motivated to be retain in teaching, it is still an issue of concern that needs to be looked at. Chapman (1994) purports that many governments wish to retain teachers at the lowest possible cost. This can lead to teacher attrition and turnover (Chapman, 1994; UNESCO, 2006). Although the colonial government of 1919-1927 in Ghana, for instance, effected a general increase in salaries of teachers aimed at retaining them and ensuring a better job performance it might not be 
enough or well implemented. Government should not take advantage of the altruistic nature of teachers but rather, must take external efforts to motivate and retain teachers. This will also help increase economy and efficiency, as well as better students' performance (Chamberlain \& Kindred, 1966).

\subsection{Conclusions}

It can be concluded that supervision, recognition and appreciation, participation in school decision-making, and salary levels, lowly motivated teachers in public basic schools in the Somanya Circuit of the Ghana Education Service. Furthermore, that factors such as salary and monetary compensation, leave benefits, good retirement plan, job security, opportunities for extra income, health benefits, accommodation, and more time to attend to other issues did not influence their level of motivation. None the less, respondents agreed that promotion and opportunities for free time during holidays are factors that influenced their level of motivation.

It can further be concluded that there was a negative correlation between teacher motivation and teacher retention in the Somanya circuit. Thus, teachers have been retained in the circuit not necessarily based on the motivation avenues presented to them but on other factors. Finally, teacher motivation does not predict teacher job performance of teachers in the Somanya circuit. The correlation between teacher motivation and teacher job performance is positive but weak. For every decrease in the motivation of teachers, the job performance of teachers will in turn decrease by a multiple of -.134 standard deviations.

\subsection{Recommendations}

The following recommendations were made based on the results of the study and conclusions.

* The Yilo Krobo Municipal Directorate of the Ghana Education Service should continue to motivate teachers by providing adequate supervision, recognition and appreciation to motivate basic school teachers in the Somanya Circuit.

* Basic school heads should continue to allow teacher-participation in decision-making in the Somanya Circuit in order to motivate them.

* The government should increase the salaries of teachers and provide better opportunities for promotion and further studies of teachers in the circuit. 
* Factors of motivation, like salary and monetary compensation, leave benefits, good retirement plan, promotion, job security, opportunities for extra income, health benefits, accommodation, free time during holidays and more time to attend to other issues, should be made available to basic school teachers in the Somanya Circuit of the Ghana Education Service.

\section{References}

Adelabu, M.A. (2005). Teacher motivation and incentives in Nigeria. http:// www.elidis.org/vfile/upload/document/0709/Teeacher_motivation_Nigeria.pdf

Agyenim-Boateng, O. E. (1996). Factors influencing recruitment and retention of teachers in selected secondary schools in Brong-Ahafo Region of Ghana. Unpublished M.Phil. Thesis. University of Cape Coast, Cape Coast.

Aheto-Tsegah, C. (2012). Education in Ghana - Status and Challenges = Common Wealth Education online. www.cedol.org. 2012/02

Akuoko, K. O., Dumah, P., Baba, W., M. (2012). Teacher motivation and quality education delivery. International Journal of Social Sciences and Interdisciplinary Research, 2 (12),

Armstrong, M., (2007). A handbook of Human resource Management Practice, Cambridge, Cambridge University Press, United Kingdom.

Ankomah, Y., Koomson, J., Bonsu, R., Oduro, G., (2005). A review of the Concept of Quality in Education: Perspective from Ghana. http:/www.edqual.org/publicatons/browse?category=Working\%20Papers.

Bame, N. K. (1991). Teacher motivation and retention in Ghana. Accra: Ghana Universities Press.

Bacharach, S. B., \& Bamberger, P. (1990). Exist and voice: Turnover and militancy intentions in elementary and secondary schools. Educational Administration Quarterly, 26 (4), 56-78.

Bell, L., \& Rhoders, C. (1996). The skills of primary school management. United Kingdom: Taylor Francis Ltd.

Bennell, P. (2004). Teacher motivation and incentives in Sub-Saharan Africa and South Asia: Knowledge and skills for development. Brighton: Knowledge, Skill and Development. Delabu, M. A., 2005.

Bennell, P., \& Acheampong, K. (2007). Teacher motivation in Sub-Saharan Africa and South Asia: Knowledge and Skills for Development. Retrieved from: r4d.dfid.gov.uk/PDF/Output/-Researchingtheiue No71.pdf

Berman, P.L. (2005). Appraisal systems for effective organisations. Prentice hall: India. 
Borg, W. R., \& Gall, M. D. (1989). Quantitative and qualitative research method. Retrieved from: apjere.usm.my/JPP_17_2001/Jilid\%2017\%20 Arkel\%2010.pdf.

Bourdon, K. H., Goodman, R., Simpson, G., \& Koretz, D. S. (2005). The strength and difficulties of questionnaire: U.S. normative data and psychometric properties. Journal of American Academy of Child \& Adolescent Psychiatry, 44 (6), 557-564.

Buckley, J., Schneider, M., \& Shang, Y. (2004). The effects of school facility quality on teacher retention in urban school districts. Washington DC: Solr/ Lucene.

Bursahoglu, Z. (2002). The effects of source of motivation in teachers' motivation level, 129(4).

Chapman, D.W. (1994). Reducing teachers absenteeism and attrition: Causes consequences and responses. Paris: UNESCO, IIEP.

Chapman, D.W., Snyder, C.W., \& Burchifeld, S.A. (1993). Teacher Incentives in the Third World. Teaching and Teacher Education, 9 (3): 301-316.

Conley, S.C., Bacharach, S.B. \& Bauer, S. (1989). The School-Work Environment and Teacher Career

Dissatisfactions. Educational Administration Quarterly, 25(1), 41-65.

Dembo, M. H. (2002). A. self-management approach. Motivation and learning. Strategies for college success (2nd ed.).

District Education Directorate (2015). End of year report, 2015. Somanya, Ghana. Emojong, J. (2004). In-service training programmes and their effects on the performance of staff at the Uganda Revenue Authority. Kampala: Unpublished Dissertation Makerere University.

Dornyei, Z. (2001). Teaching and Researching Motivation, England: Pearson Education Limited. Education for All Global Monitoring Report, (2005) UNESCO, Paris.

Feiman-Nemer, S. (1996). Teacher mentoring: A critical review. Washington DC: Eric Digest.

Gritz, R. M., \& Theobald, N. D. (1996). The determinant of teacher attrition in upstate. New York, Washington DC: Washington DC State Data.

Hallack, J. (1990). Investing in the future: Setting educational priorities in the developing world. Paris: UNESCO, IIEP.

Hansen, M. L., Lien, D. S., Gavalluzzo, L. C., \& Wenger, J. W. (2004). Relative pay and teacher retention: An empirical analysis in a large urban district. Alexandria: Alexandria CNA Corporation. 
Hoy, W. K., \& Miskel, C.G. (2013). Educational administration: Theory, research and practice (3 ${ }^{\text {rd }}$ ed.). New York: Random House.

Herzberg, F., Mausner, B., Snyderman, B. (1956). The Motivation to Work. New York: Wiley and Sons.

Ingersoll, R. M. (2001). Teacher turnover and teacher shortages. An Organisational Analysis, 38(3), 499-534.

Johnson, S. M., Berg, J. H., \& Donaldson, M. L., (2005). Who stay in teaching and why: A review of the literature on teacher retention. Boston: Harvard Graduate.

Kadzamira, E. C. (2006). Teacher motivation and incentives in Malawi. Retrieved from: http://communities.eldis.org/.59at4573/Teacher \%20motivation \%20and\%20incentive

Locke, E. A. (1984). A New York at Work Motivation: Theory V. In Franke, R.(Ed.). The Science of Productivity (pp. 43-60), San Francisco: Jessey-Bass.

Lope, Z.A., \& Habibah, P. E. (2004). Improving the Teaching Profession through Understanding Educators' Self-motivation. PJPR, Vol. 19, Nos. 1-2

McWilliams, H. O. A., \& Kwamena-Poh, M. A. (1975). The development of Eeducation in Ghana. New Edition. London: Longman Group Ltd

Mulllins, L, J. (2002). Management and organisational behaviour (6 $6^{\text {th }}$ ed.). United Kingdom: Prentice Hall.

Mussazi, J. C. S. (1985). The theory and practice of educational administration. London: Macmillan Publisher Limited.

NaseerUd Din, M. (2008). A Study of Motivation Techniques Used By Heads Of Institutions of Higher Education and Their Impact on the Performance of Teachers. Contemporary Issues In Education Research Second Quarter, Volume 1, Number

NaseerUd Din, M., Tufail, H., Shereen, S., Nawaz, A., \& Shahbaz, A. (2012). Factor Affecting Teacher Motivation at Secondary School Level in Kohat City. Interdisciplinary Journal of Contemporary Research in Business, Vol. 3, No. 10

Nayyar, R. Z. (2005). Lahore school of economics. Retrieved from: www.lahareschoolofeconomics: edu.p/cvs/DrNayyar.aspx

Ofoegbu, F. L. (2004). The Teacher Motivation: A Factor for Classroom Effectiveness and School Improvement in Nigeria. CollegeStudentJournalFundArticles.com. Access on 12 July, 2010. 
Opare, J. A. (1999). Academic achievement in private and public schools: Management make the difference. Journal of Educational Management, 2, 1-2.

Osei-Fosu, A. K. (2011). Evaluating the impacts of the capitation grant and the school feeding programme on enrolment, attendance and retention in schools: The case of Weweso Circuit. Journal of Science and Technology, 31(3).

Owusu-Acheaw, E (2016). The influence of motivation on teacher job performance and teacher retention in the Somanya circuit of the Ghana Education Service. MPhil thesis of University of Cape Coast, Cape Coast, Ghana.

Parveen, A. (2011). System and reforms of higher education in Pakistan jbssnet.com/journal/vol2No20. November $2011 / 28$ pdf.

Paynter, J.L. (2004). The motivational profiles of teachers: Teachers preferences for extrinsic, intrinsic and moral motivators [Dissertation]. Baltimore: The John Hopkins University.

Qayyum, A., \& Siddique, M. (2003).Let's Enhance the Performance of the Teachers: A Study of Motivational Techniques used by School Heads. Journal of Elementary Education, 13: pp.28-33.

Robinson, S. P., \& Longton, G. (2003). Organisational behaviour. United Kingdom: Prentice Hall.

Sam, F. K., Effa, B., \& Osei-Owusu, B. (2014). Exploring issue in Ghana. A case study of public senior high schools in Kwabre East district of Ashanti region -Ghana. Journal of Education and Practice, 5(1),

Soglo, N. E. K. (2000). Teacher recruitment and retention in teacher training colleges in the Volta Region of Ghana. Unpublished Masters Dissertation. University of Cape Coast, Cape Coast.

Tanim, C. (2006). The British journal of sociology, 57(1).

Aheto Tsegah, C. (2011). Education in Ghana - Status and Challenges. Commonwealth Partners Report

UNESCO (2006). Guideline for inclusion: Ensuring ace to education for all. Retrieved from: unesdoc.uneco.org/images/0014/001402/140224e.pdf.

UNESCO (2006). Teacher Motivation, Compensation and Working Conditions. International Institute for Educational Planning (IIFEP) www.unesco.org.iiep.

Utuka, G. (2000). Factors influencing recruitment of teachers in the newly established senior secondary schools in the Ashanti Region of Ghana. Unpublished. Unpublished Masters Dissertation. University of Cape Coast, Cape Coast. 
Winbilah, A. K. (1999). Recruitment and retention of basic school teacher's in the Bawken East District of Ghana. Unpublished M.Ed. Dissertation. University of Cape Coast, Cape Coast

Zembylas, M., and Papanastasious, E. (2004). Job satisfaction among school teachers in Cyprus. Journal of Educational Research, 90, 103-109. 